\title{
Characteristic Features and Comparative Analysis of Essential Oil Composition of Selected Species of Ocimum Sanctum L. Through GCMS
}

\author{
Prerna Sharma ( $\square$ presharma31@yahoo.com) \\ Maharishi Markandeshwar University \\ Kumud Upadhyaya \\ Kumaun University
}

\section{Research}

Keywords: O. Genus, Antibacterial, Plant, Natural source, Tulsi, GC-MS, Eugenol

Posted Date: January 16th, 2021

DOI: https://doi.org/10.21203/rs.3.rs-139700/v1

License: (1) This work is licensed under a Creative Commons Attribution 4.0 International License. Read Full License 


\begin{abstract}
Background: The main aim of this research is to provide a literature of the Ocimum plant, to know the significance of the Ocimum species carried out by pharmacognostical study and experimental design for GC-MS. Ocimum are very important for their therapeutic potentials. among the most important aromatic herbs for its enormous medicinal properties.
\end{abstract}

Methods: An extreme Attention has been put on those literature reports wherein the utilization of Tulsi and their pharmacognostical study has been done by performing morphological and microscopic leaf and experimental design by using essential oil by GC-MS instrumentation method

Results: The utilization of these characteristics would be important for the drug discovery scientist to develop a specific formulation of the crude drug, which will be a magical therapeutic agent in the future, with the many advantageous. GC-MS chromatogram of the Ocimum sanctum, Ocimum canum and Ocimum gratissimum oil showed major peaks and has been identified after comparison of the mass spectra with NIST library, indicating the presence of three phytocomponents. From the results GC-MS study suggested that anethole which is well reported antimicrobial compound is more in 0 . canum (2.66\%) in comparison to 0 . sanctum $(1,28 \%)$ but absent in 0 . Gratissimum. The results indicated that the antimicrobial activity is more in 0 . canum due to presence high amount of anethole in comparison to 0. Gratissimum, and $O$. Sanctum. The GC-MS study suggested that anethole which is well reported antimicrobial compound is more in 0 . canum $(2.66 \%)$ in comparison to 0 . sanctum $(1,28 \%)$ but absent in 0 . Gratissimum.

Conculsion: The result showed that microscopic character of $O$. canum, with the characteristic GC MS analysis of the extracts, to identify different species of the ocimum plant. Ocimum sanctum $\mathrm{L}$. and further experiments are required for better exploitation of essential oil for its commercial purposes.

\title{
Background
}

Ocimum sanctum L., commonly known as holy basil, Among the plants known for medicinal values, plants of genus Ocimum belonging to family Lamiaceae Ocimum are very important for their therapeutic potentials. among the most importantaromatic herbs for its enormous medicinal properties, such as anticancerous, antidiabetic, spasmolytic, carminative, cardioprotective, anthelmintic and diaphoretic actions. Ocimum sanctum possesses various biological activities such as analgesic, antipyretic, antidiabetic, hepatoprotective, hypolipidemic, immuno-modulatory, and anti-inflammatory. It observed that some of its phytoconstituents such as eugenol, linoleic acid, luteolin, $\beta$-sitosterol prevent skin, liver, oral and lung cancers through increasing the anti-oxidant activity, inducing apoptosis, altering the gene expression, and inhibiting metastasis. It has been observed that Ocimum sanctum leaves showed inhibition of growth of tumor cells. It is assumed that Ocimum sanctum would be an effective medicine so far in inhibiting the all kinds of cancer.[1-4]

Ocimum sanctum is used as a traditional medicine and possesses various biological activities because of the active components present in the plant such as eugenol, linoleic acid, oleic acid, rosmarinic acid, ocimarin, isorientin, orientin, aesculectin, aesculin, chlorgrnic acid, galuteolin, gallic acid, citronellal, camphene, sabinene, dimethylbenzene, ethylbenzene, vitamin C, and calcium.[5-7]

\section{Methods}

\section{Collection, identification and authentication of selected plants}

A Collection of all three types of tulsi leaves named Rama Tulsi (Ocimum sanctum), Krishna Tulsi (Ocimum canum) and Vana Tulsi (Ocimum gratissimum) of the genus Ocimum were collected from the local area of haryana India. Identification of this was confirmed by Dr. RS Jayasomu, Head, Raw material Herbarium and Museum Division (RHMD), NISCAIR, New Delhi, where a voucher sample (Ref.No. NISCAIR/RHMD/Consult/-2016/3000-27-2) has been deposited. For further studies in Pharmacognostical manner, Phytochemical analysis and Extraction, leaves were collected, shade dried and converted them into fine powdered form

\section{Pharmacognostical Study}

The pharmacognostical study has been done by performing morphological and microscopic analysis of Leaf as per WHO guidelines. Microscopic Studies

Transverse section (TS) of leaf and powder characteristics were identified with (Phlorogucinol $+\mathrm{HCL}$ ) reagents such as chloral hydrate and glycerine to study the cells, fibre, xylem vessels, starch grains, and calcium oxalate crystals. Permanent slide of TS of Leaf was prepared to 
observe the presence and arrangement of cellular structures as per the procedure of Johansen[8] and the representative figures were taken with the help of microscopic image camera.

Experimental Design for GC-MS

GC-MS analysis of the Rama Tulsi (Ocimum sanctum), Krishna Tulsi (Ocimum canum) and Vana Tulsi (Ocimum gratissimum) essential oil was performed using below given instruments information.

Thermo Trace 1300GC coupled with Thermo TSQ 800 Triple Quadrupole MS.

For GC - THERMO TRACE 1300 GC

For MS - THERMO TSQ 8000

- Software used: XCalibur 2.2SP1 with Foundation 2.0SP1

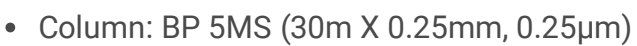

- Column Makeup: 5\% Phenyl Polysilphenylene-siloxane

- Injector: S (Split)

- Injection volume:2.0 $\mu \mathrm{L}$

- Split Ratio: 20:1

- Injector temp: $250^{\circ} \mathrm{C}$

- MS transfer line temp: $230^{\circ} \mathrm{C}$

- Ion source temp: $230^{\circ} \mathrm{C}$

- Mass Range :40-700

- Carrier Flow:1.0ml/min

- Oven Program:

Initial Temp: $50^{\circ} \mathrm{C} \quad$ Hold time: $1.0 \mathrm{~min}$

Temp 1: $220^{\circ} \mathrm{C} \quad$ Hold Time: $5.0 \mathrm{~min}$

Rate: $5^{\circ} \mathrm{C} / \mathrm{min}$

- Detector: MS TSQ 8000

- Library used: NIST 2.0

Microscopical evaluation

The powder Microscopy of selected varieties of Tulsi such as, Rama Tulsi (Ocimum sanctum), Krishna Tulsi (Ocimum canum) and Vana Tulsi (Ocimum gratissimum) were done and evaluated for the characterization of the drug through below given pictures in their respective sequence. These pictures are critically evaluated with the specific microscopic features.

\section{a) Characterization of $O G$}

Gas Chromatography-Mass Spectrometry analysis

A Perkin-Elmer gas chromatograph (model 8700), with flame ionization detector (FID) was used for the chemical analysis of the Rama Tulsi (O. sanctum), Krishna Tulsi (O.canum) and Vana Tulsi (O. gratissimum) essential oil. The temperatures of the injector and detector were set at 220 and $290^{\circ} \mathrm{C}$, respectively. The column thermostat temperature was started from $80^{\circ} \mathrm{C}$ and raised to $220^{\circ} \mathrm{C}$ at the rate of $4^{\circ} \mathrm{C}$ min- 1 , whereas initial and final temperatures were held for 3 and $10 \mathrm{~min}$, respectively. The carrier gas was helium with a flow of $1.5 \mathrm{~mL}$ min-1. A sample of $1.0 \mu \mathrm{L}$ was injected (split ratio 100:1). For quantification purposes a built-in data-handling program of the equipment (PerkinElmer) was used. The essential oil composition was reported as a relative percentage of the total peak area ${ }^{12-14}$.

\section{Table 1}

\section{Chemical Composition of volatile oil extract from 0 . gratissimum analyzed by GC-MS.}




\begin{tabular}{|llcccc|}
\hline RT & Compound Name & Probability & Peak Area & Area \% & Molecular Weight \\
\hline 10.75 & 1,6 -Octadien-3-ol, 3,7-dimethyl- & 70.62 & 264140772.25 & 1.98 & 154 \\
\hline 10.75 & Linalyl acetate & 5.63 & 264140772.25 & 0.36 & 196 \\
\hline 12.36 & Linalyl isobutyrate & 1.68 & 199242845.32 & 1.50 & 224 \\
\hline 13.49 & 1,5-Dimethyl-1-vinyl-4-hexenyl butyrate & 1.95 & 200305251.13 & 1.50 & 224 \\
\hline 15.17 & Estragole & & & & \\
& & 23.88 & 1042348110.23 & 7.38 & 148 \\
\hline 17.97 & 2-Hexyl-1-octanol & & & & \\
\hline
\end{tabular}

\section{b) Characterization of OS}

\section{Table 2}

Chemical Composition of volatile oil extract from 0 . Sanctum analyzed by GC-MS.

\begin{tabular}{|llcccc|}
\hline RT & Compound Name & Probability & Peak Area & Area \% & Molecular Weight \\
\hline 21.24 & 1-Dodecanol, 2-octyl- & 3.46 & 136866142.39 & 0.54 & 298 \\
\hline 21.24 & 1-Decanol, 2-octyl- & 2.95 & 136866142.39 & 0.54 & 270 \\
\hline 22.35 & 2-methyltetracosane & 3.26 & 19645383.15 & 0.08 & 352 \\
\hline 24.09 & Tetracontane, 3,5,24-trimethyl- & 4.27 & 358800273.33 & 1.41 & 604 \\
& & & & & \\
\hline 26.82 & Octatriacontyl pentafluoropropionate & 2.09 & 29166462.68 & 0.11 & 696 \\
& & & & & \\
\hline 38.29 & Sulfurous acid, butyl octadecyl ester & 4.07 & 1702077568.54 & 6.70 & 390 \\
\hline
\end{tabular}

\section{c) Characterization of O C}

\section{Table 3}

Chemical Composition of volatile oil extract from 0. Canum analyzed by GC-MS. 


\begin{tabular}{|c|c|c|c|c|c|}
\hline RT & Compound Name & Probability & Peak Area & Area \% & Molecular Weight \\
\hline 13.47 & 1,6-Octadien-3-ol, 3,7-dimethyl & 57.31 & 1415878189.55 & 4.08 & 154 \\
\hline 13.47 & Linalyl isobutyrate & 1.82 & 1415878189.55 & 4.08 & 224 \\
\hline 16.77 & Estragole & 43.16 & 10188160501.52 & 29.39 & 148 \\
\hline 16.77 & Benzene, (1-propynylthio)- & 0.91 & 10188160501.52 & 29.39 & 148 \\
\hline 18.68 & 10-MethyInonadecane & 18.24 & 57180203.88 & 0.16 & 282 \\
\hline 18.68 & Sulfurous acid, 2-propyl undecyl ester & 4.77 & 57180203.88 & 0.16 & 278 \\
\hline 19.52 & 2-Hexyl-1-octanol & 8.03 & 155688172.07 & 0.45 & 214 \\
\hline 20.07 & 1-Octadecyne & 5.13 & 55019667.38 & 0.16 & 250 \\
\hline 20.07 & 1-Heptadecyne & 5.34 & 55019667.38 & 0.16 & 236 \\
\hline 22.07 & Oxalic acid, cyclobutyl octadecyl ester & 6.49 & 223103118.93 & 0.64 & 396 \\
\hline 24.54 & & & & & \\
\hline 25.50 & Levomenol & 24.39 & 231862815.33 & 0.67 & 222 \\
\hline
\end{tabular}

\section{Results And Discussion Gc-ms Analysis}

The hydro-distillation of essential oil from leaf extract of Ocimum sanctum L. yielded pale yellow aromatic oil. GC-MS chromatogram of the Ocimum sanctum, Ocimum canum and Ocimum gratissimum oil showed major peaks and has been identified after comparison of the mass spectra with NIST library, indicating the presence of three phytocomponents. From the results. The GC-MS study suggested that anethole which is well reported antimicrobial compound is more in 0 . canum $(2.66 \%)$ in comparison to 0 . sanctum $(1,28 \%)$ but absent in 0 . Gratissimum. The results indicated that the antimicrobial activity is more in 0 . canum due to presence high amount of anethole in comparison to $O$. Gratissimum, and $O$. Sanctum.

\section{Conclusion}

The summarized information has been focused to the microscopic character of $O$. canum, with the characteristic GC MS analysis of the extracts, to identify different species of the ocimum plant. The retention time of each chemical constituent is reported for future identification of the plant and their variant. In the future it will be a source of literature to identify variant plant species for the quality production of the plant. Ocimum sanctum $\mathrm{L}$. and further experiments are required for better exploitation of essential oil for its commercial purposes. 


\section{Abbreviations}

$\mathrm{OS}=$ Ocimum . sanctum

O. $=$ Ocimum Genus

COX-1 $=$ Cyclooxygenase- 1

coX-2 = Cyclooxygenase-2

VEGF = Vascular endothelium growth factor

WHO $=$ World Health Organization

COPD = Chronic obstructive pulmonary disease),

$\mathrm{IBD}=$ Inflammatory bowel syndrome

$\operatorname{DMBA}=7$, 12- dimethylbenz(a)anthracene

VEGFR-3 = Vascular Endothelial Growth Factor Receptor 3

VLA-4 = Very Late Antigen-4

\section{Declarations}

\section{ETHICS APPROVAL AND CONSENT TO PARTICIPATE}

No human participants were involved in this paper and no new data were collected; thus, ethical approval was not required.

\section{CONSENT FOR PUBLICATION}

All authors consent to publication in the journal.

\section{AVAILABILITY OF DATA AND MATERIALS}

All relevant data are within the paper and its Supporting Information files.

\section{CONFLICT OF INTEREST}

The authors declared no potential conflicts of interest with respect to the research, authorship, and/or publication of this article.

\section{FUNDING}

The authors received no financial support for the research, authorship, and/or publication of this article.

\section{ACKNOWLEDGEMENTS}

We would like to thank KU contributed to English language editing and extraordinary support in this research article.

\section{AUTHORS' CONTRIBUTIONS}

PS contributed to manuscript conception, design, planning and writing in all areas of the manuscript and contributed to manuscript conception, design, planning and writing of literature pertaining to pharmacognosy and phytochemistry related components. KU contributed to conception and design and critical revisions of content. All authors have approved the paper to be published.

\section{AUTHOR INFORMATION}

Corresponding Author

Ms. Prerna Sharma (Research Scholar), Uttarakhand Technical University, Dehradun-248007

Assistant Professor, MM College of Pharmacy, Maharishi Markandeshwar(Deemed to be University), Mullana-Ambala, India (133207) 
E-mail: presharma31@yahoo.com

Dr. Kumud Upadhyaya

Department of Pharmacognosy, ${ }^{\text {b}}$ Kumaun University, Nainital (Uttarakhand) 263001, India

Mob No: 9897280964

Email: upkuupku@gmail.com

\section{References}

1. S. Godhwani, J.L. Godhwani, D.S. Was, O. sanctum- A preliminary study evaluating its immunoregulatory profile in albino rats, J. Ethnopharmacol. 24 (1988) 193-198.

2. T. De Jesus Faria, R.S. Ferreira, L. Yassumoto, J.R.P. De Souza, N.K. Ishikawa, A. De Melo Barbosa, Antifungal activity of essential oil isolated from O. gratissimum L. (eugenol chemotype) against phytopathogenic fungi, Brazilian Arch. Biol. Technol. (2006).

3. N. Dubey, N. Kishore, J. Varma, S. Lee, Cytotoxicity of the essential oils of Cymbopogon citratus and O. gratissimum I Request PDF, Indian J. Pharm. Sci. 59 (1997) 263-264.

https://www.researchgate.net/publication/294517338_Cytotoxicity_of_the_essential_oils_of_Cymbopogon_citratus_and_0._gratissimum (accessed March 21, 2019).

4. L. Jirovetz, G. Buchbauer, M.B. Ngassoum, L.T. Ngamo, O. Adjoudji, Combined investigation of the chemical composition of essential oils of O. gratissimum and Xylopia aethiopica from Cameroon and their insecticidal activities against stored maize pest Sitophilus zeamais, Ernahrung. 29 (2005) 55-60. https://eurekamag.com/research/004/078/004078453.php (accessed March 21, 2019).

5. J.A.O. Ojewole, Analgesic, anti-inflammatory and hypoglycaemic effects of Rhus chirindensis (Baker F.) [Anacardiaceae] stem-bark aqueous extract in mice and rats, J. Ethnopharmacol. 113 (2007) 338-345..

6. WHO, IUCNNR, WWF, The conservation of medicinal plants., 1993. https://apps.who.int/iris/bitstream/handle/10665/41651/2831701368_en.pdf?sequence=1\&isAllowed=y (accessed March 21, 2019).

7. V.. Kamboj, Herbal medicine, Curr. Sci. 78 (2000) 35-39.

8. Johansen DA. Plant Microtechnique. 1st ed. New York and London: McGraw-Hill Book Co., Inc., 1940.

9. V.N. Offiah, U.A. Chikwendu, Antidiarrhoeal effects of O. gratissimum leaf extract in experimental animals., J. Ethnopharmacol. 68 (1999) 327-30. http://www.ncbi.nlm.nih.gov/pubmed/10624896 (accessed March 21, 2019).

10. C.J. Njoku, L. Zeng, I.U. Asuzu, N.H. Oberlies, J.L. McLaughlin, Oleanolic Acid, a Bioactive Component of the Leaves of O. Gratissimum (Lamiaceae), Int. J. Pharmacogn. 35 (1997) 134-137.

11. L.O. Orafidiya, S.K. Adesina, O.A. Igbeneghu, E.O. Akinkunmi, G.E. Adetogun, A.O. Salau, The effect of honey and surfactant type on the antibacterial properties of the leaf essential oil of O. gratissimum Linn. against common wound-infecting organisms, Int. J. Aromather. 16 (2006) 57-62.

12. Adams RP , Identification of essential oil components by gas chromatography/mass spectrometry. Allured Publishing Corpo- ration, Carol Stream 115 (2007)

13. Allman MA, Pena MM, Pang D (1995) Supplementation with flaxseed oil versus sunflower seed oil in healthy young men consuming a low fat diet: effects on platelet composition and function. Eur J Clin Nutr 49:169-178

14. Asha MK, Prashanth D, Murli B, Padmaja R, Amit A Anthelmintic activity of essential oil of Ocimum sanctum and eugenol. Fitoterapia 72(20001) 669-670

\section{Tables}

Table 1

Chemical Composition of volatile oil extract from 0 . gratissimum analyzed by GC-MS. 


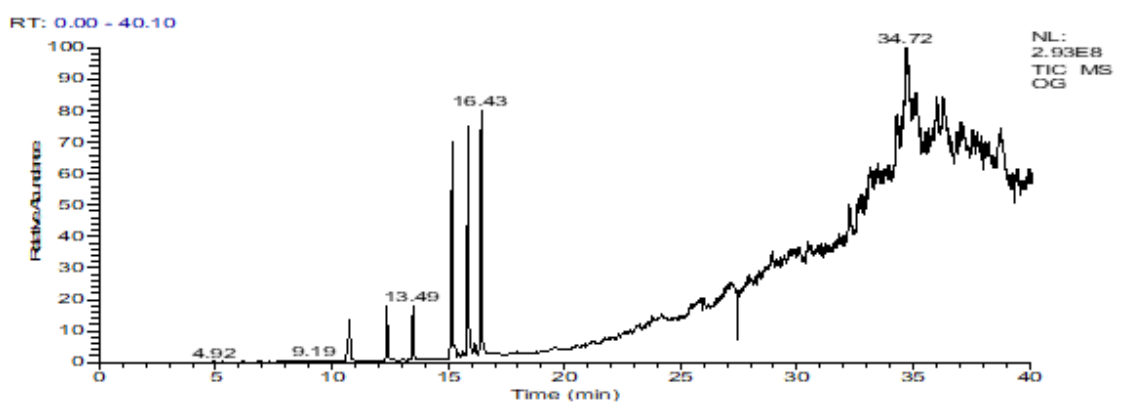

\begin{tabular}{|llllll|}
\hline RT & Compound Name & Probability & Peak Area & Area \% & Molecular Weight \\
\hline 10.75 & 1,6-Octadien-3-ol, 3,7-dimethyl- & 70.62 & 264140772.25 & 1.98 & 154 \\
\hline 10.75 & Linalyl acetate & 5.63 & 264140772.25 & 0.36 & 196 \\
\hline 12.36 & Linalyl isobutyrate & 1.68 & 199242845.32 & 1.50 & 224 \\
\hline 13.49 & 1,5-Dimethyl-1-vinyl-4-hexenyl butyrate & 1.95 & 200305251.13 & 1.50 & 224 \\
\hline 15.17 & Estragole & & & & \\
& & 23.88 & 1042348110.23 & 7.38 & 148 \\
\hline 17.97 & 2-Hexyl-1-octanol & & & & \\
\hline
\end{tabular}

\section{Table 2}

Chemical Composition of volatile oil extract from $O$. Sanctum analyzed by GC-MS.

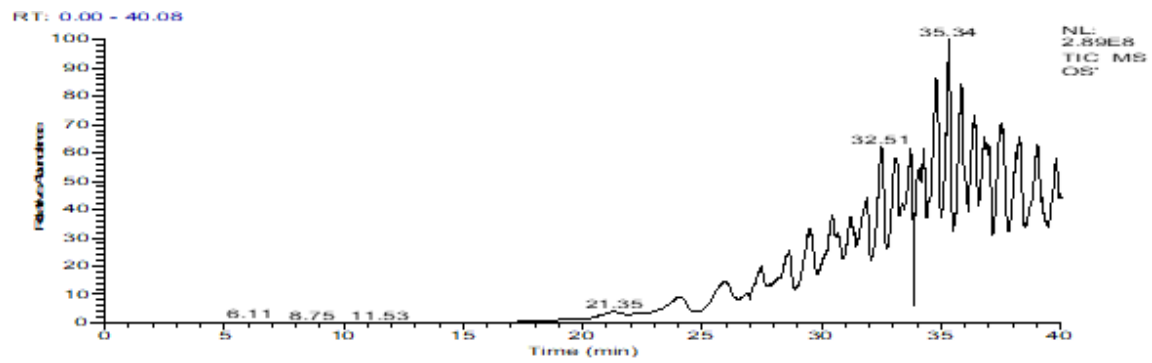




\begin{tabular}{|llcccc|}
\hline RT & Compound Name & Probability & Peak Area & Area \% & Molecular Weight \\
\hline 21.24 & 1-Dodecanol, 2-octyl- & 3.46 & 136866142.39 & 0.54 & 298 \\
\hline 21.24 & 1-Decanol, 2-octyl- & 2.95 & 136866142.39 & 0.54 & 270 \\
\hline 22.35 & 2-methyltetracosane & 3.26 & 19645383.15 & 0.08 & 352 \\
\hline 24.09 & Tetracontane, 3,5,24-trimethyl- & 4.27 & 358800273.33 & 1.41 & 604 \\
\hline 26.82 & Octatriacontyl pentafluoropropionate & 2.09 & 29166462.68 & 0.11 & 696 \\
\hline 38.29 & Sulfurous acid, butyl octadecyl ester & 4.07 & 1702077568.54 & 6.70 & 390 \\
\hline
\end{tabular}

Table 3

Chemical Composition of volatile oil extract from 0 . Canum analyzed by GC-MS.

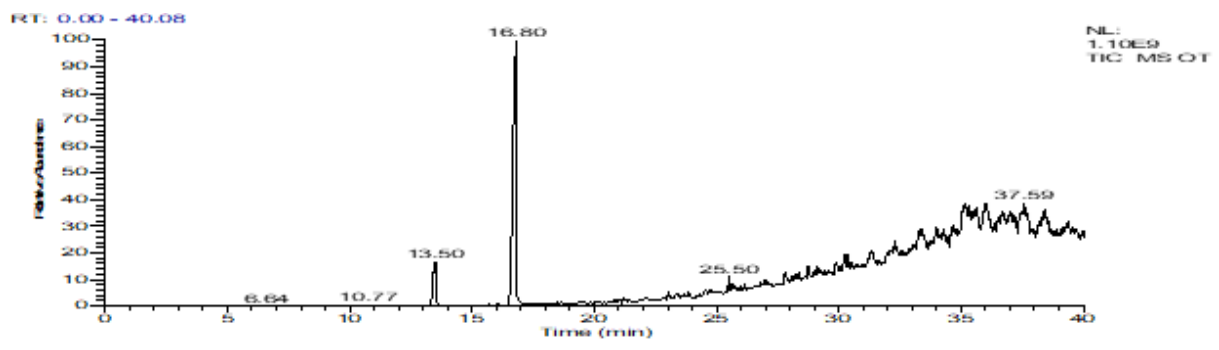




\begin{tabular}{|c|c|c|c|c|c|}
\hline RT & Compound Name & Probability & Peak Area & Area \% & Molecular Weight \\
\hline 13.47 & 1,6-Octadien-3-ol, 3,7-dimethyl & 57.31 & 1415878189.55 & 4.08 & 154 \\
\hline 13.47 & Linalyl isobutyrate & 1.82 & 1415878189.55 & 4.08 & 224 \\
\hline 16.77 & Estragole & 43.16 & 10188160501.52 & 29.39 & 148 \\
\hline 16.77 & Benzene, (1-propynylthio)- & 0.91 & 10188160501.52 & 29.39 & 148 \\
\hline 18.68 & 10-MethyInonadecane & 18.24 & 57180203.88 & 0.16 & 282 \\
\hline 18.68 & Sulfurous acid, 2-propyl undecyl ester & 4.77 & 57180203.88 & 0.16 & 278 \\
\hline 19.52 & 2-Hexyl-1-octanol & 8.03 & 155688172.07 & 0.45 & 214 \\
\hline 20.07 & 1-Octadecyne & 5.13 & 55019667.38 & 0.16 & 250 \\
\hline 20.07 & 1-Heptadecyne & 5.34 & 55019667.38 & 0.16 & 236 \\
\hline 22.07 & Oxalic acid, cyclobutyl octadecyl ester & 6.49 & 223103118.93 & 0.64 & 396 \\
\hline 24.54 & & & & & \\
\hline 25.50 & Levomenol & 24.39 & 231862815.33 & 0.67 & 222 \\
\hline
\end{tabular}

Figures 

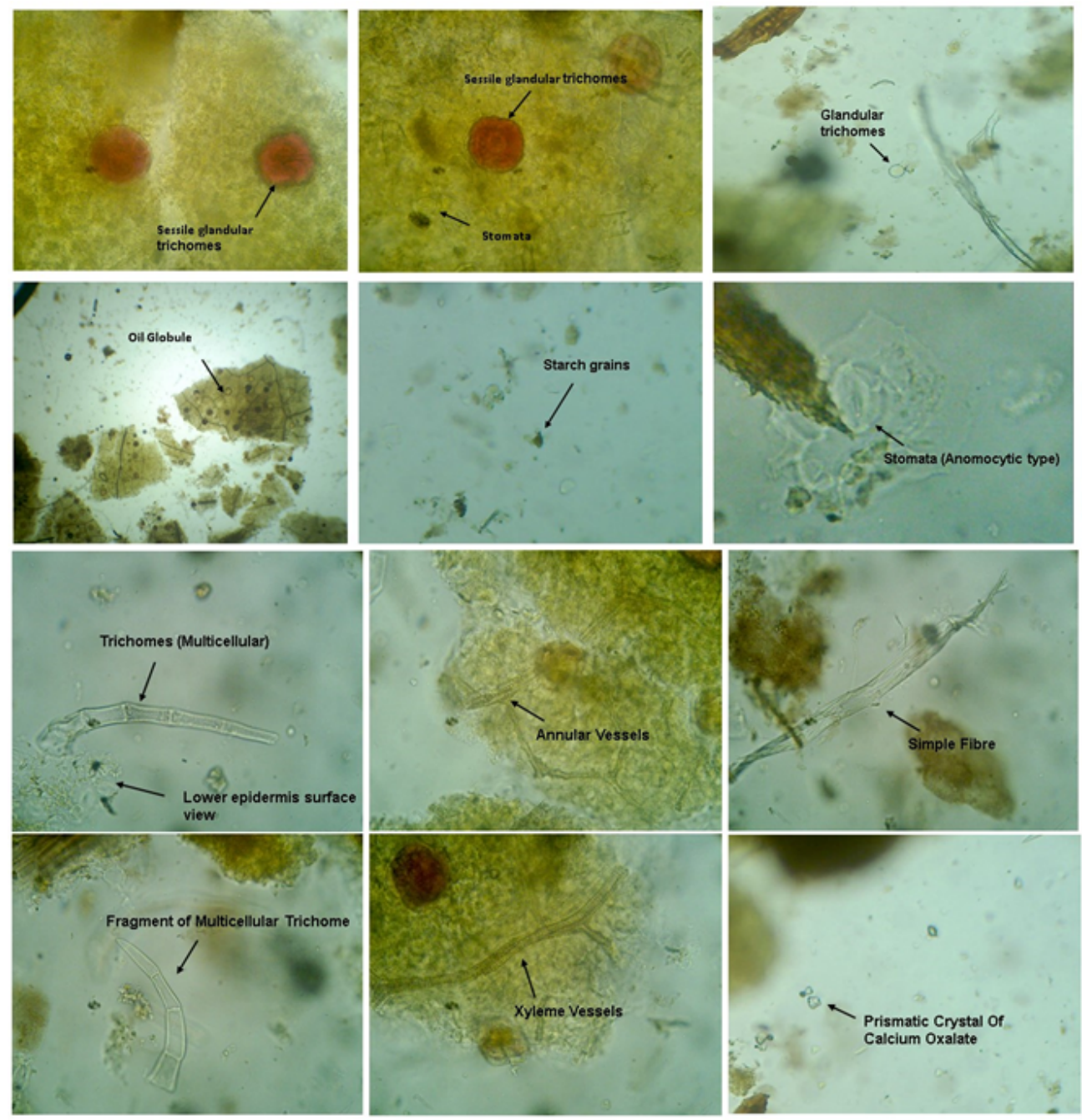

\section{Figure 1}

Powder Microscopy of Rama Tulsi (Ocimum sanctum) 

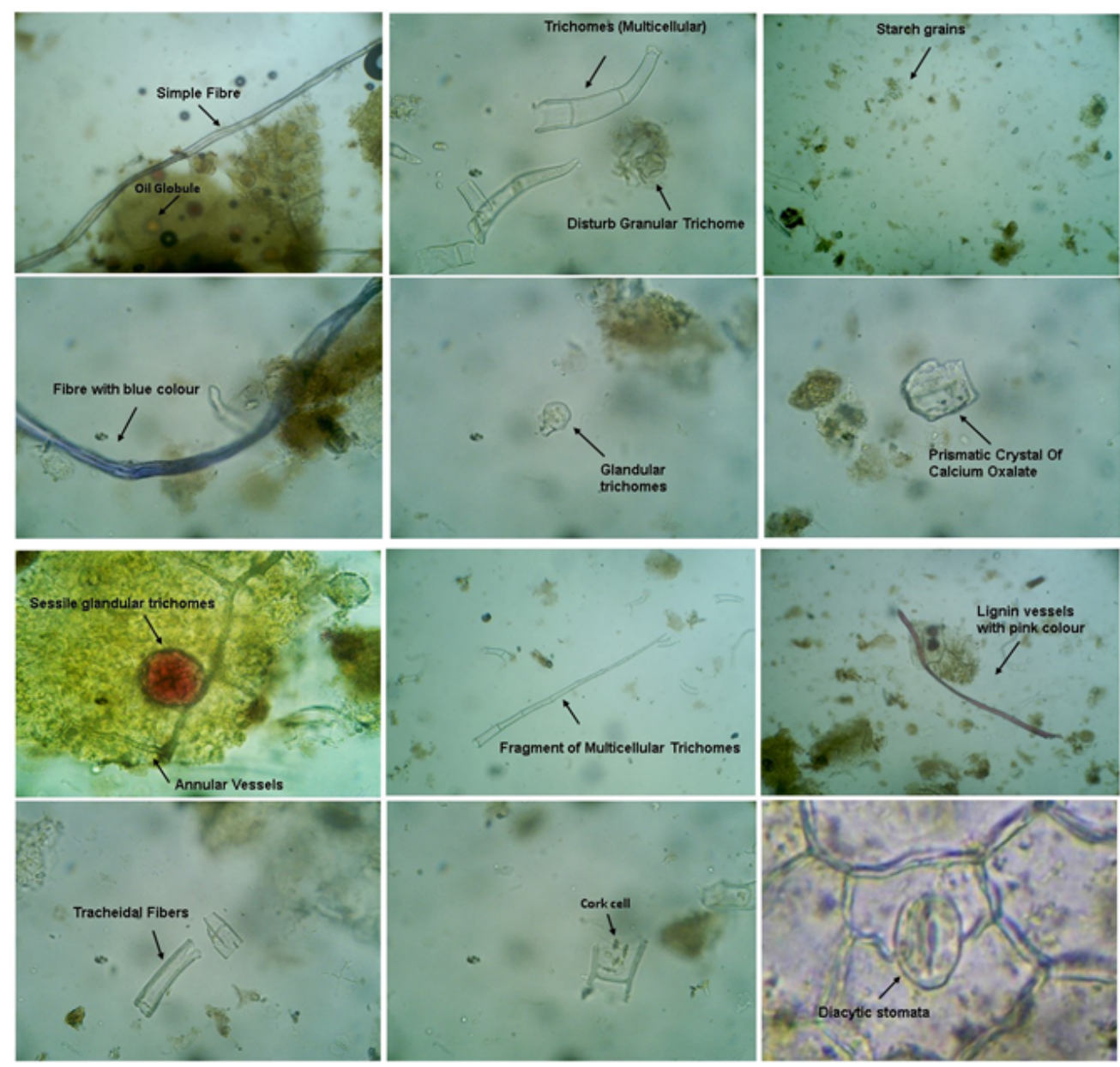

\section{Figure 2}

Powder Microscopy of Krishna Tulsi (Ocimum canum) 

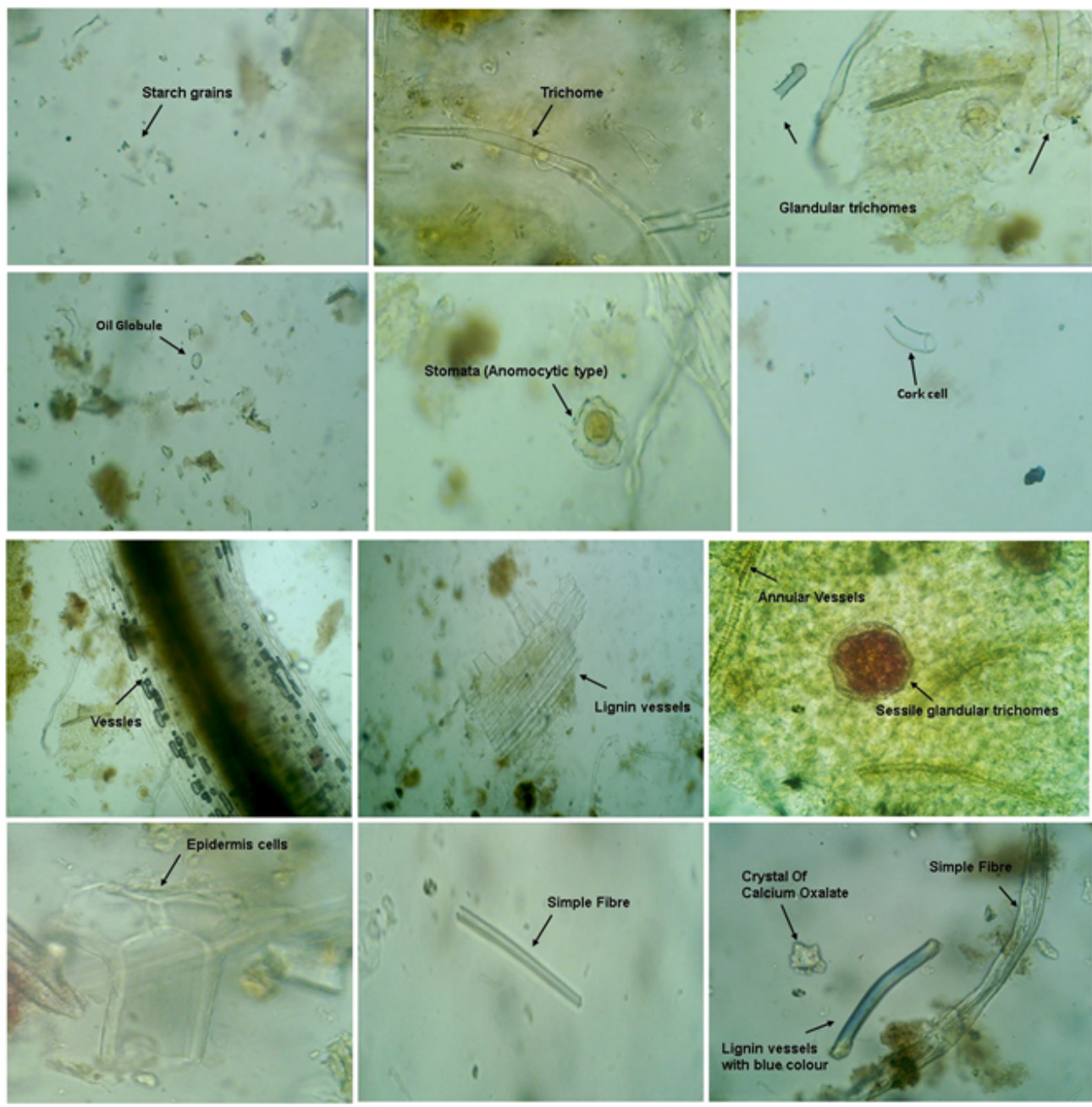

\section{Figure 3}

Powder Microscopy of Vana Tulsi (Ocimum gratissimum) 